\title{
Teaching and Testing ESP at Iranian Universities: A Critical View
}

\author{
Goodarz Alibakhshi \\ Language teaching department, Yasouj University, Iran \\ Email: alibakhshi_goodarz2000@yahoo.com \\ Hassan Ghand Ali \\ Payame Noor University, Iran \\ Davoud Padiz \\ Yasouj University, Iran
}

\begin{abstract}
Comparing general English teaching with ESP teaching, we certainly notice both similarities and differences. The difference is that many general English language teachers are trained to become teachers of English while the great majority of ESP teachers are not trained as such. ESP teachers need, therefore, to orientate themselves to a new environment for which they have not generally been prepared. Regardless of the existence of this significant difference, as Jordan (1997) believes, ESP teachers obviously have much in common with any language teacher. The ESP teacher needs to take account of developments in linguistics and learning theory, aims to keep up with current views on the place of learners in the education system, and has to confront the new technologies offered as aids to improve pedagogy. What distinguishes, the ESP teachers from many teachers in the world of ELT, however, is the additional and crucial need to understand, the requirements of other professionals, either academic or occupational, the differences in learning conditions in terms of both learners' needs, age, etc. This study is an attempt to critically view of ESP teachers' roles in Iran to see whether they follow the right procedures in ESP classrooms or not. To carry out the study, some ESP classrooms in some universities were observed and the teachers' main activities were compared with those activities in the provided checklist. The results indicate that ESP teachers in our country are not teaching English and their activities do not reflect innovations in teaching and learning.
\end{abstract}

Index Terms-ESP, teaching, testing, improvement

\section{INTRODUCTION}

So far we have concerned ourselves with different stages of ESP program planning, from the initial data collection, through the design of materials, to the structuring of classroom and learning environment. If we follow the commonly practiced model of ESP program planning in which teaching and testing are viewed as the final stages, now we come to the final sections to consider the role of the ESP teacher, in particular, to consider in what ways the ESP teacher's lot differ from that of the general English teacher. Then, we make an attempt to discuss the past and the present status of testing in ESP program planning. Finally, we suggest some guidelines to improve ESP program in terms of both teaching and testing. The discussion of the two separate but interdependent stages of any ESP program is given in two different sections.

\section{THE ROLE OF ESP TEACHER}

Comparing general English teaching with ESP teaching, we certainly notice both similarities and differences. The difference is that many general English language teachers are trained to become teachers of English while the great majority of ESP teachers are not trained as such. ESP teachers need, therefore, to orientate themselves to a new environment for which they have not generally been prepared. Regardless of the existence of this significant difference, as Jordan (1997) believes, ESP teachers obviously have much in common with any language teacher. The ESP teacher needs to take account of developments in linguistics and learning theory, aims to keep up with current views on the place of learners in the education system, and has to confront the new technologies offered as aids to improve pedagogy. What distinguishes, the ESP teachers from many teachers in the world of ELT, however, is the additional and crucial need to understand, the requirements of other professionals, either academic or occupational, the differences in learning conditions in terms of both learners' needs, age, etc.

Jordan (1997) also believes that ESP teachers have different jobs. The jobs can be specified as catalyst, organizer, advisor, coordinator, and friend. He also believes that because teachers enter into a number of professional rolerelationships, they are the focus of many different attitudes from different sources (e.g. learners, organizers, sponsors, etc). 
Flowedew and Peacock (2001) argues that the role of teacher will vary according to the type of syllabus and course and which part of the world it takes place in. As Richards and Rodgers (2001) believe, teachers roles are related both to assumptions about language and language learning at the level of approach. Some methods are totally dependent on the teacher as a source of knowledge and direction; others see the teacher's role as catalyst, consultant, guide, and model of for learning; still others try to "teacher- proof" the instructional system by limiting teacher initiative and by building instructional content and direction into texts or lesson plans. Teachers and learner roles define the type of interaction characteristic of classrooms in which a particular method is being used.

In line with Richards and Rodgers, no one can claim that ESP teachers should perform the same activities in their different ESP classrooms. That is, naturally speaking, as ESP classes are different in terms of learners' different purposes and different fields of study, teachers, therefore, are required to have a variety of teaching activities in their classrooms according to their learners. A comprehensive discussion of teachers' role in the learner- centered approach and teacher-directed approach is contained in Richards and Rodgers (2001). In contrast to teacher's roles in General English teaching which has been explored to a great extent, only a few applied linguists have attempted to elaborate on the ESP teacher's roles which are quoted in the following parts of the study.

Robinson (1991) suggests that the key quality needed by the ESP teacher is flexibility: the flexibility to change from being a general language teacher to being a specific teacher, and the flexibility to adapt to different groups of students, often at very short notice.

Jarvis (1983) cited in Robinson (1991) encapsulated the overall abilities needed by an ESP teacher:

1. Analyze SP language and situations;

2. Evaluate textbooks and other sources;

3. Evaluate learners attainment;

4. Devise performance objectives for learners;

5. Design or interpret syllabuses;

6. Design or interpret schemes for work;

7. Devise teaching and learning strategies;

8. Devise individual but interrelated teaching sessions;

9. Produce materials;

10. Organize teaching/ learning sessions;

11. Assess achievements of objectives.

Kennedy and Bolitho (1984) cited in Robinson (1991) made a list of the likely requirements of an ESP teacher such as: developing a working knowledge of the students' subject; dealing with the pastoral problems of students a long way from homes and families; and preparing the students for specific entry requirements of English language exams.

Johns (1981) cited in Robinson (1991) mentioned ESP teachers problems. The problems, in rank order of importance, were:

1. Low priority in timetabling;

2. Lack of personal/ professional contact with subject teachers;

3. Lower status/grade than subject teachers;

4. Isolation from other teachers of English doing similar work;

5. Lack of respect from students.

\section{SUGGeSTIONS TO IMPROVE ESP TEACHING}

Critically viewing the review of the related literature on ESP teaching in general and ESP teachers' roles in particular, we can find out that in contrast to the great development which has been made in ESP material development, teaching and teachers' roles in ESP program planning have not been paid adequate attention. In this part of the study, I try to provide some solutions to the prevalent problems in ESP so that we cam make a change in the current practiced ESP teaching methodology in our country. The main suggestions and solutions are listed as follow:

1. As Sifakis (2003) believes, majority of ESP learners are adults. Therefore, applying the adult education framework to ESP curriculum development seems to be very vital if we intend to take into consideration all influential variables especially learners' variables. By 'adult education' (AE) I mean the international interdisciplinary study of adults as learners and/or trainees of all types and in all environments (J. Rogers, 1989; A. Rogers, 1996). By 'English for specific purposes' (ESP), I refer to the wide area that concentrates on all aspects of the specific-purpose teaching of English and encompasses the academic (EAP) and vocational/ occupational (EOP) frameworks (Dudley-Evans \& St John, 1998). The same perspective is presumed here to apply to the teaching of any language for specific purposes (Widdowson, 1983).

While ESP and AE share, as we will see, similar theoretical constructs (e.g. a concern for learner autonomy and motivation, self-confidence, self-directed learning, etc.), ESP is predominantly considered to be an approach (in the sense that Richards and Rodgers, 1986, gave to the term) to the teaching of the English language (Dudley-Evans \& St John, 1998; Hutchinson \& Waters, 1987), which makes it relevant to practically all age-groups (except, perhaps, younger learners) and, arguably, all target situations (as the necessities-needs-wants curricular orientation of Hutchinson and Waters, 1987, seems to imply). AE, on the other hand, concentrates on the teaching of subjects that involve either 
manual skills (e.g. pottery) or knowledge-transfer (e.g. history) to a particular group of learners, namely, adults. In this article, I will not be challenging the 'ESP-as-an-approach' perspective — on the contrary, I will be focusing on elements from $\mathrm{AE}$ that can be fruitfully implemented in all forms of ESP course design.

In line with Sifikis (2003), I strongly believe that ESP teaching due to the specific characteristics of the adult learners is to a great extent different from teaching general English. I also believe that adult learners' greater sense of perspective and ability to make judgments (about themselves and others) based on accumulated experience, combined with their inherent autonomy and need for establishing clear goals, can be fruitfully implemented in ESP teaching/learning situations. This can be achieved by making the ESP learner an active participant, not only in the actual learning process, but also in the syllabus and lesson planning stage. Therefore, it can be argued that ESP teachers are both counselors and teachers.

On the one hand, the ESP teacher is responsible for promoting, whenever possible, methodology-specific communicative strategies that enhance the learners' adulthood- oriented considerations. This would involve the integration of self-directed learning techniques with task-based activities that enhance the learners' problem-solving skills and ability to reflect on previous experience.

On the other hand, ESP teachers act as advisors or counselors to their adult learners. Counseling is 'the process of helping an individual discover and develop his educational, vocational, and psychological potentialities and thereby to achieve an optimal level of personal happiness and social usefulness'. The counselor's function is finding ways to both appreciate and enhance learners' learning and studying needs as well as increasing the scope of adult learners' exploratory behavior by offering psychological assistance where necessary. Such counsel may have to do with a host of different situations, ranging from helping learners adjust to the new learning situation to boosting their self-confidence in micro-skill-oriented issues to helping them with unexpected personal crises (e.g. death in the family, divorce, accidents, etc). While counseling is especially applicable in small ESP classes, large classes can also benefit from it if the ESP teacher draws the learners' attention to it, highlights its importance at the beginning of classes and prompts them to consult him/her when need arises. However, as Lozanov 1979) and others have stressed, teacher counseling has a strictly speaking pedagogic function and should never be equated with (and therefore can never replace) professional therapy.

As Wheeler (2000) believes, the ESP teaching process can benefit from a teacher who treats learners as adults and has the following 'qualities of a competent therapist': 'a good person, intelligent, creative, sincere, energetic, and warm towards others, responsible and of sound judgment'. In the first stage of learning, teachers/counselors must establish themselves with the student as being attractive, trustworthy and expert, whereas 'personal attributes such as warmth and positive regard, cultivating hope, being non-judgemental and accepting' (Wheeler, 2000) are also considered important. The therapist's character and interpersonal style are also necessary aspects, as are acceptance, emotional stability, openmindedness, commitment, genuineness, interest in people, confidence, sensitivity and fairness (Pope, 1996, cited in Wheeler, 2000). Finally, it is important for the learner to appreciate from the outset that the teacher is able to communicate and is non-competitive, uncomplicated, a good listener and openly reflective on his/her own practice (especially important in very specific ESP situations.

2. Sullivan and Girginer (2002) believe effective ESP programs require relevant materials, knowledgeable instructors, and teamwork with subject matter professionals. They provided an example of one process used by a teacherresearcher to increase and expand each of these aspects. That is, one of the authors was asked to teach English to future pilots and air traffic controllers in Turkey, and, though she had had experience teaching English, she had little knowledge of the actual English language needs of her students. As she looked over the books she was given, she felt strongly that these standard English language books were neither appropriate nor sufficient. Her search for other material that focused on specific language needs of air traffic personnel, especially in this Turkish setting, yielded little. After discussing this situation and ways to become more familiar with the needs of her students, she decided to document actual language used by pilots and air traffic controllers at work in order to increase her awareness and provide a basis for materials development. Her decision was based, in part, on Hutchinson and Waters' (1987) comments about the lack of specific content knowledge of many ESP teachers, and the need for them to orient themselves to a new environment.

Based on the result of their study it can be argued that ESP teachers who have little knowledge of the specific language needs of their students and are not familiar with the discourse of their students, are recommended to work with professionals and analyze their discourse. In line with their findings and Hutchinson and Waters (1987), I believe that if there is to be meaningful communication in the classroom, it is necessary that there be a common fund of knowledge and interest between teacher and learner. This implies inevitably that the ESP teacher must know something about the subject matter of the ESP materials. To put it in another way, understanding the discourse of the students' subject matters through negotiation between ESP teachers and learners can facilitate teaching process.

3. Since ESP programs vary worldwide, there is no single, ideal role description for an ESP practitioner. In addition to the routine tasks of a language teacher, the ESP practitioner may be required to deal with administrative, personnel, cross-cultural, interdisciplinary, curricular, and pedagogical issues that may be unfamiliar to ESOL teachers.

Several traits and skills have been identified as important for success in teaching ESP: flexibility, adaptability, creativity, resourcefulness, well developed organizational and managerial/leadership skills, effective interpersonal and 
cross-cultural communication skills, and mature problem-solving and decision-making skills (Hutchinson \& Waters 1990; Jackson 1994, 1995; Robinson 1991).

ESP teacher education programs that are problem-based and practitioner oriented can help student teachers develop the requisite skills and attributes by providing "a kind of classroom apprenticeship for professional decision making" and reflection. In line with Jackson (1998), it can be put forward that the case method is ideally suited for this purpose since cases can bring the world of the ESP practitioner into the classroom and help student teachers vicariously experience the problems and challenges involved in the sometimes messy world of ESP.

As Jackson (1988) cites, the careful selection of cases for an ESP teacher education program is crucial to the success of the learning experience and must take into consideration the goals of the program as well as the needs and interests of the students. The following are some general attributes of reality-based decision cases that work particularly well in programs that are planned to foster the skills that teachers need in ESP practice:

1. The connection between the key issues in the cases and the course syllabus is explicit;

2. The cases are compelling, well-written narratives or videotaped scenes;

3. The detailed narratives are "richly contextualized, multilayered account containing a variety of issues for analysis;

4. The cases do not have simple solutions;

5. They end in a cliffhanger with students keen to find out how the situation was resolved; and

6. There is an element of generalizability.

To sum it up, in line with Jackson I believe that teachers who enter the profession of ESP may find themselves teaching first-year engineering students in Qatar, post-registration nursing students in Indonesia, MBA students in Hong Kong or pre-law students in London, political science students in Iran, etc. The possibilities seem endless as ESP continues to expand around the globe to meet the demands for English as the medium of science, technology, trade, and tourism. How can we as teacher educators best prepare teachers for the challenges they could face in these diverse roles and avoid Hutchinson's and Waters' (Hutchinson \& Waters 1990) admonition that "ESP teachers are all too often reluctant dwellers in a strange and uncharted land"?

I strongly support the use of reality-based decision cases in teacher education programs to better prepare teachers for ESP practice. The analysis of cases can help teachers make connections between knowledge and practice and can stimulate and foster the skills and confidence that they will need in order to feel at ease and competent in the professional community of ESP practitioners.

Moreover, cases are very flexible tools that are or can be made relevant and of interest to the specific needs of student teachers, whether in pre-service or in-service teacher education programs. In settings where useful, culturally appropriate teacher education materials may be difficult to obtain, cases can be a way of providing opportunities for reflection on relevant, meaningful teaching practice. In order for this pedagogy to become widely used and accepted, however, it is imperative that experienced ESP practitioners document their experiences through cases and make these "windows on practice" accessible to others. Let's take ESP practice out of the closet.

4. In reflective pedagogy, teachers are not considered as only consumers of predetermined materials. Teachers as the real managers of the classrooms and as those who are touching a lot of relevant issues in the classroom should be given a chance to contribute to the ESP program from the first to the last stage. To train such ESP teachers, I think we need to design a separate field of study or at least an interdisciplinary field which aims at educating and training ESP teachers. In ESP teacher education programs, teachers should acquire the basic principles of material developments and materials adaptation so that that they can be effective in learning situations which are predictable by course designers. They should also be taught how to make use of technology in their ESP classes.

\section{TESTING IN ESP PROGRAM}

Generally speaking, evaluation is an important stage of any education system. Reviewing the literature on testing, we can infer that testing in education in general and language teaching in particular has gone through different developmental stages. A very important and useful issue for all language teachers to bear in their minds is that each approach to language teaching has one specific testing and evaluation system. To simply put it, each method of language teaching is evaluated via one particular testing approach (e.g. audio-lingual method and discrete point tests have the same theoretical assumptions). The emergence of each approach to teaching paved the way for one corresponding testing approach.

Chronologically speaking, different eras in language testing can be mentioned. To put it in another way testing history can be divided into there different eras: pre -scientific, psychometric-structural, and communicative.

Critically speaking, a significant development has been made in the ESP materials. As we know, we should evaluate our students based on what they are instructed. Therefore, a significant development in ESP testing seems to be not only necessary but only the only solution to the prevailing problems in ESP/EAP areas. While, although different approaches to materials development in ESP have been practiced in the world of ESP, no real innovation in testing methods has been made. That is, we expected to evaluate our students based on the real materials which they are learning; whereas, we are making use of inappropriate testing approaches. In this part of study, we intend to provide an overview of issues in EAP assessment. We also intend to criticize the currently practiced testing/ assessment method in ESP programs and provide some solutions. 


\section{ASSESSMENT IN EAP PROGRAMS}

Assessment in EAP programs is carried out for a variety of purposes which can be roughly categorized under the general headings of learner assessment and course evaluation. On one hand, course evaluation helps to assess whether the course objectives are met and whether the course is doing what is designed to do. On the other hand, as with any language course, learner assessment is carried out to assess student performance at strategic points in the course. Learner assessment is carried out for two functions classified as achievement, and placement which are also used in any general English course. As different functions of tests have been well elaborated on by different applied linguists and psychometrics, in this part of the study only a short definition of each is given.

\section{A. Placement Tests}

The aim of placement test is to determine the learners' state of knowledge before the ESP program begins. Placement test should indicate firstly whether the learners need the course at all and secondly, should a need be indicated, what form the course should take? A placement test is, therefore, both a proficiency and a diagnostic test. To put it in another way, based on the results of a placement test, one can understand whether the learners are proficient in the skills required or not. If yes, no further instruction is needed. If the learners are not proficient, a placement test can indicate how far and in what ways the learner falls short of the proficiency level.

\section{B. Achievement Tests}

Achievement tests are used to determine the extent to which learners have learned what has been taught during a course of instruction. Brown (1996) points out, the results of achievement tests/assessments can be used not only to inform teachers about the learners' attainment of instructional objectives, but also to provide feedback on the effectiveness of program.

\section{CURREnt Practiced EAP TEStS}

In EAP contexts, there are some recognized and influential forms of tests which are used for the purposes of admission to universities in English-speaking countries and sometimes to local universities in our country. These tests are, TOFEL, IELTS, MCHE, GRE, etc. the emergence of such tests led to generation of a huge commerce in textbooks, sample tests, and specific purpose preparation courses.

\section{Criticizing the EAP tests}

The current practice of EAP tests can be criticized from different points of views. The main criticisms are mentioned as follows:

1. Unfortunately, in some countries especially in our country, EAP test scores are used as 'criterion-referenced passfail indicators'. Such practice may lead to the exclusion of qualified candidates. As we do not whether the candidates with scores below the university cut- offs are able to complete courses successfully or not, the common practice of EAP tests needs to be critically revised.

2. The application of cut-off scores for admission to universities may result is raising different thought provoking questions such as: what is an appropriate level of proficiency for entering the universities?, should this level of proficiency be the same for students of different majors?, and do institutions follow a systematic method of test administration and interpretation?

3. As we know ESP describes language programs designed for groups or individuals who are learning with an identifiable purpose and clearly specifiable needs. And we also know that tests should be measuring what the students are instructed and are expected to learn at the end of instruction program. While, the critical analysis of the EAP tests indicate that these tests are administered in different parts of the world and all the students, regardless of their purposes, needs, and interests, should take the same tests with the same items and forms. The practice of such general tests is against the theoretical assumptions underlying ESP programs because they are based on the objectives of EAP programs.

4. As mentioned in the earlier parts of the study, material design in ESP has gone through different stages of development. It began with register analysis and ended with genre analysis, and probably it will face inevitable changes in future. Whereas, there is evidence suggesting that TOFEL, which is based on structural linguistics and did not contribute to the emergence of ESP, is frequently used in EAP contexts. Therefore, the content and construct validity of these so called EAP/ESP tests can be strongly criticized.

5. As the purpose of ESP programs is to facilitate acquiring the other subject materials not the language itself, the function and the forms of ESP tests should be different from those of general English programs. In other words, we should lay more emphasis on course assessment rather than learner assessment. Therefore, the currently used GRE or IELTS can not be accepted as the only instruments used in evaluation and assessment. Furthermore, the learners should not be assessed in order to diagnose whether they should pass or fail the course but to provide them with remedial instructions so that they can benefit more from the ESP/ EAP programs.

6. It seems that it is necessary to develop tests which are based on all components of ESP/EAP programs. That is, in addition to three traditional testing approaches applicable to general English programs, new approach to testing is needed to account for the recent developments made to ESP program. 


\section{SUGGESTIONS}

Reviewing the literature of testing in academic contexts and criticizing the current practice of academic tests, the following solutions to the prevalent can be given:

a) Academic tests, if administered, should not aim at accepting some and rejecting some others. They should aim at providing information about the students' levels of proficiency and determining the right channel of instruction.

b) New types of tests should be developed to incorporate the contents of ESP programs. These tests should aim at evaluating ESP courses in order to improve the practiced courses.

c) As some tests are used to select students, their reliability and validity should be meticulously estimated. Especially, the threshold level and cut off points of each test should be carefully determined.

d) It must be carefully investigated whether students with high academic tests are really more successful than those with low academic test scores or not. If not, them the administration of these tests to evaluate students' proficiency seems to be not only unnecessary but detrimental to some.

e) Academic tests if necessary, should measure the areas of language which language learners need. If some students do not need speaking skill, then why should we evaluate their speaking skill through TOFEL tests? If they only need writing to accomplish their courses, then why not writing test be used rather than listening tests?

f) Assuming that all the students do not need the same amount of English, why the students who are not good at English are not allowed to study at Ph.D level in Iran, although majority of them are qualified enough to complete their courses?

g) Traditional approaches to testing are not applicable to ESP programs. New approaches to assessment such as portfolio assessment should be practiced. Teachers can not evaluate students' achievements alone. A team including course designers, learners, sponsors, etc. is needed.

\section{CONCLUSION}

This paper aims at reviewing teaching and testing in ESP program planning. It was concluded that in addition to general characteristics of a successful teacher, an ESP teacher should know the principles of adult learning, should contribute to the development of all the components of ESP program, and should make an effort to get acquainted with the discourse and content of the subject matter which s/he is supposed to teach in order to have meaningful communication.

In terms of testing it can be said that a total innovation in academic tests in terms of both functions and forms is actually needed. Some of the commonly practiced tests are based on learning and linguistic theories which did not have significant impacts on the emergence of ESP. Therefore, new approach to testing is needed to account for the recent development in ESP materials. And also, it is concluded that instead of traditional tests, the new approaches to tests especially portfolio assessment should be practiced.

\section{REFERENCES}

[1] Dudley-Evans, T., \& St John, M. J. (1998). Developments in English for specific purposes: an interdisciplinary approach. Cambridge: Cambridge University Press.

[2] Flowerdew, J. and Peacock, M. (2001). Research Perspectives on English for Academic purposes. CPU

[3] Hutchinson, T., \& Waters, A. (1990). English for specific purposes: A learning-centered approach. Cambridge: Cambridge University Press.

[4] Hutchinson, T. \& Waters, A. (1987). English for specific purposes. Cambridge: Cambridge University Press.

[5] Johns, A. (1997). Text, role, and context. Cambridge: Cambridge University Press.

[6] Jordan, R. R. (1997). English for academic purposes. Cambridge: Cambridge University Press.

[7] Lozanov, G. (1979). Suggestology and outlines of suggestopedy. New York: Gordon and Breach.

[8] Jackson, J. (1994). From ESL to EAP: Teacher preparation for success. Paper presented at the MEXTESOL conference in Ixtapa, Mexico in October.

[9] Jackson, J. (1995). Integrating language and content: EAP teacher education. Paper presented at the TESOL convention in Long Beach, CA, USA in March.

[10] Jackson, J. (1998). Reality-Based Decision Cases n ESP Teacher Education: Windows on Practice. English for Specific Purposes, Vol.17, No.2, pp 151-187, 1998

[11] Richards, J. and Rodgers, T.S. (2001). Approaching and Methods in Language Teaching. CPU

[12] Robinson, P. (1991). ESP today: a practitioner's guide. Hertfordshire, U.K.: Prentice Hall International (U.K.) Ltd.

[13] Rogers, A. (1996). Teaching adults. Buckingham, Philadelphia: Open University Press.

[14] Rogers, J. (1989). Adults learning. Milton Keynes: Open University Press.

[15] Sifakis, N.C. (2003). Applying the adult education framework to ESP curriculum development: an integrative model. English for specific purposes. Vol. 22, pp, 195-211ss

[16] Sullivan, P and Gringer, H. (2002). The Use of Discourse Analysis to Enhance ESP teacher knowledge: an example using aviation English. English for Specific Purposes, Vol. 21,pp, 394-404

[17] Wheeler, S. (2000). What makes a good counsellor? An analysis of ways in which counsellor trainers construe good and bad counselling trainees. Counselling Psychology Quarterly, 13(1), 65-83.

[18] Widdowson, H. G. (1983). Learning purpose and language use. Oxford: Oxford University Press. 
Goudarz Alibakhshi is an assistant professor at Yasouj University, Iran. He has been different courses such as language testing, teaching methodology, ESP, applied linguistics, and linguistics at state universities in Iran. He has published several papers in international journals.

Hassan Ghand Ali has been teaching reading, speaking, writing and general English at Payame-noor University in Iran. He has presented some papers in international Conferences.

Davoud Padiz has been teaching general English at Yasouj University, Iran for a couple of years. 